This item was submitted to Loughborough's Institutional Repository (https://dspace.lboro.ac.uk/) by the author and is made available under the following Creative Commons Licence conditions.

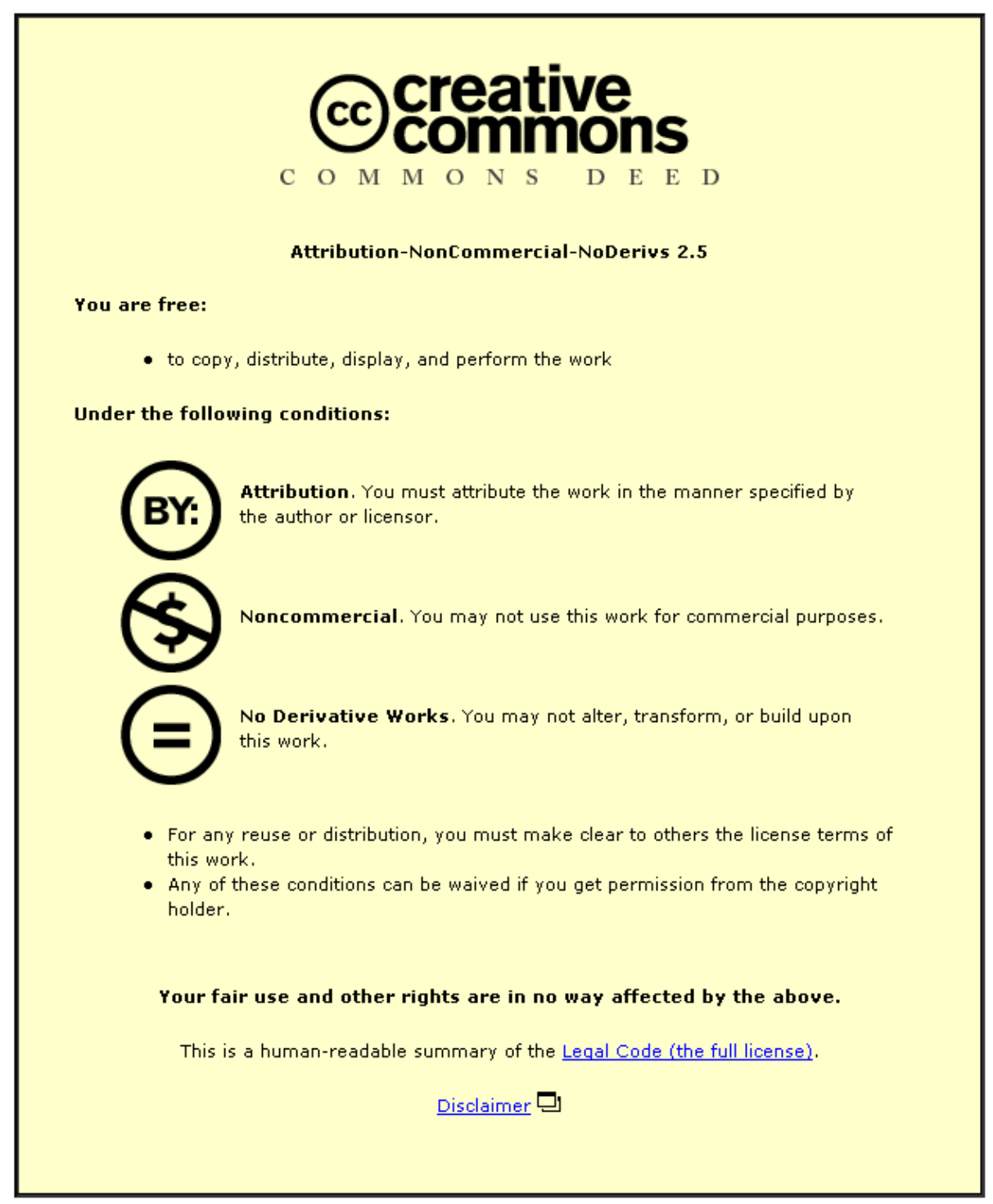

For the full text of this licence, please go to: http://creativecommons.org/licenses/by-nc-nd/2.5/ 


\title{
Fostering Collaboration within an SME Services Organisation
}

Udityasinh Gohil, Prof. Patricia Carrillo, Dr. Kirti Ruikar, Prof. Chimay Anumba

\begin{abstract}
Core operations of many small service organisations involved in collaboration are largely on a project basis. However, every organisation has core processes and management processes that are equally important (Kohlbacher, 2010). The objective of this paper is to establish a business process model for such a project-based service organisation (PBSO) where equal importance is given to core as well as management processes, to create a sustainable collaboration. The focus of the paper was a PBSO and hence a case study of a PBSO firm lead to the discussion of the advantages of involving collaborators in all processes of the organisation.
\end{abstract}

\section{Keywords}

Project-Based Service Organisations, SME, Business Process Model, Case Study, IDEF0

\section{Introduction}

Over the last few decades, many knowledge-based service organisations had been heavily involved in inter-organisational collaboration. These organisations need to understand the effect of their network and organisational boundaries by analysing the firm's interactions with other organisations (Paper, 1998; Ritter and Gemunden, 2004). However, understanding the effect of these organisational boundaries can be difficult due to the organisation's inherent complexity (Paper, 1998). The failure to formally describe it can lead to ambiguity and inconsistency between the collaborators (Wysocki, 2004). A way to tackle this complexity is through modelling the organisation to study parts of an organisation without losing the overall context. A formal modelling of organisation helps in understanding the organisation and leads to reduced issues with communication and ambiguity.

The core operations of such service organisations are largely on a project basis and hence these project processes are the core processes of these organisations. However, every organisation has core processes and management processes that are equally important (Kohlbacher, 2010). In such project-based service organisations, a major amount of the time is spent on temporary project settings with transient project structures comprising internal and external stakeholders. Hence, an issue in such a project setting is the difficulty of these service organisations to involve their collaborators in management (non-core or support) processes to integrate knowledge and structures when projects are viewed as 'singular ventures' in themselves. A formal structure is required for the management of collaboration to avoid the above mentioned complexity, ambiguity and inconsistency in management processes. The value of collaboration within such project based service organisations and their collaborators will be enhanced if formalised and well- 
defined core as well as management (non-core) processes are in place. Such processes would cover the roles and responsibilities of all stakeholders and the flow of information and knowledge during active project periods as well as between projects.

This paper's aim is to impart the shift from a 'project-based' model where more importance is given to core processes, to an organisational perspective with a strategic intent with equal importance to core as well as management processes, especially for service organisation with a collaborative network in place. For a sustainable collaboration in such project-based organisations, there is a requirement to involve collaborators in all the processes of the organisation including the management processes. A project based outlook does not always create appropriate methods to communicate the involvement of collaborators in such management processes. Consequently, an alternative view is developed by constructing an appropriate process model of the enterprise communicating the strategic as well as governance roles of the collaborators. The paper argues for a need to balance the outlook of a projectbased organisation and to give it an enhanced strategic intent that is easily visible to collaborators as well as clients. This has been achieved by the development of a business process model for a case study organisation.

The paper structure consists of a research method, literature discussion of project-based service organisations as well as appropriate process modelling techniques followed by the background of the case study. The penultimate section proposes a new process model and the last section identifies the implications through concluding discussions.

\section{Research Method Adopted}

The first step for the current research was to establish the research focus. Research focus for the current work has been the work of Project-Based Service Organisations (PBSO) especially involved in collaborative relationships. The research wanted to help generate a strategic intent for such organisations that was communicated to each internal as well as external stakeholder. An obvious question to such an arrangement is how a PBSO firm with collaborative relationships currently works and how it can be better interpreted by all involved in this relationship through a strategic focus. Along with an extensive literature review, the answer to such research questions are best answered when they are targeted to limited events or conditions in reallife context to better understand the phenomenon. Hence, an investigation to a contemporary phenomenon in a real-life context is required and such studies are best carried forward with case study research (Yin, 1994, Stake, 1995).

The selection of the case study for the current research was based on an organisation which was evidently a PBSO with a high dependence on collaborative working relationships for running its business. In addition, the researcher's unique position within the organisation helped to get excess to multiple sources of data through the documentation of business processes, archival records of the organisations, extensive interviews with organisation's 
directors as well as collaborators, direct observation and participationobservation.

Preliminary observations were carried out to better understand the current way of working in the PBSO firm. For this purpose both the directors of the PBSO firm and two collaborating associates were interviewed. This exercise consisted of questions to understand how the organisation is currently organised in terms of their working protocols. The preliminary observations confirmed that the collaborators were involved in only the project related processes and hence were unsure of the expectations of the work while they are between projects. In addition, the observations confirmed that the lack of any document outlining the business processes and their ownerships is responsible for this project-based view to the organisation. Hence, the 'as-is' processes were fragmented with a very project-centric view.

The selection of an appropriate tool or technique for the new process development was based on the requirements of the PBSO firm. These requirements were based on the need for the process model to be complete and accurate but not too complicated to make it easily understandable to all stakeholders. The development of the new model required extensive information on how the organisation should be managed and how this management would be carried out. The information collected from all these discussions was further analysed with the assistance of a case study organisation, to identify the current problems due to lack of management of information and communication lapses. The primary sources for data collection in these studies have been interviews and observations. The choice of data collection is based on wanting to hear the 'story' of the processes involved in the collaborative environment.

Based on the information provided by the case study firm's directors and its' collaborators, a new business process model was developed. The intention of developing this model is to create a central document for everyone involved in the PBSO that helps understand the process structure of the organisation's working as well as to guide the collaborators towards working with the PBSO firm from a strategic viewpoint. Once the process model was developed, it was reviewed and approved by the interviewees. Hence, the iterative process which followed ensured that the development of the process was rigorous.

The review consisted of two-way communication with the purpose of reaching consensus on the story conveyed through the process model. Since the reviewers were involved with the organisation, they were aware of the background of the organisational system being modelled and how it will affect once the changes are implemented. The completed business process model was then evaluated against the issues identified as being responsible for the difficulties the case study organisation was facing due to its project-based features. This evaluation helped to discover if the process model would help in providing a better strategic intent and governance mechanism to the PBSO.

The strength of this research method is that it tried to identify the extensive variables involved in developing a detailed process model. However a 
limitation is that the observations are highly personal in the current case study as the business process context of a PBSO firm with collaborative relationships has a major emphasis on human interactions and relationships.

\section{The Project-Based Service Organisation}

The context of this paper are 'Project-Based Service Organisations' (PBSO). However, to lead on to the definition of PBSO, it is important to first understand what are Project-based organisations. Project-based organisations are an emerging organisational form which integrates diverse and specialised intellectual resources and expertise. Hobday (2000) identifies project-based organisations as an organisation where the project is the primary business mechanism for coordinating and integrating all the main business functions of the firm. Therefore, there is no formal functional coordination across project lines. Sydow et al. (2004) further state that in such organisations projects are embedded in permanent contexts, sometimes resulting in no communication of the strategic intent of the organisation (Thiry et al., 2007).

Whitley (2006) further suggests that such organisations usually organise their work around recurrent projects, and often rely on outsiders (collaborators) for completing individual tasks, however barely retaining a core group of employees for initiating, organising and conducting separate projects. In essence, the employees and collaborators are affiliated to the organisational context rather than the project, making the project work routine rather than the exception. An example of such an affiliation towards the organisational context would be active involvement of collaborators in strategic organisational decision making processes like selection of new tools and

methodologies. Lastly, Soderlund (2000) gives a typology of temporary/permanent organisations, where 'project organisations' imply that employees have permanent contracts with the organisation and external collaborators have strong collaborative relationships in place.

Project-based organisations have been an integral part of the service industry. A number of service organisations adopt a project-centric organisational culture. The aim of these service organisations is to deliver value to their clients. Such organisations are often considered the hallmarks of the knowledge-based economy (European Monitoring Centre, 2005). Hence, PBSO are a subset of business services. Such organisations are usually involved with providing knowledge-intensive inputs to business processes of organisations, e.g. business and management consultants, architectural or engineering consultancies or even holding companies involved in management activities.

PBSOs are increasingly involved in collaborative arrangements to distribute some of the work originally covered by employees as internal operations. One of the prominent motivations for such collaborative arrangements is the concept of focusing on core competencies (European Monitoring Centre, 2005). Many PBSO are small firms especially in the consultancy area. These 
firms supply a wide range of services, which eventually result in some overlap in the services they provide. Such overlap is typically due to two possible reasons, a) because their core competence services are not providing them with enough business, or b) the small firms are involved with their major client's strategies and hence try to develop special services to integrate their inputs for the clients (Toivonen, 2004).

Figure 1 below shows an example of such overlapping of types of services provided by a PBSO. For example, management consultants offer a range of services that sometimes overlap with those provided by other specialist disciplines such as lawyers, scientists and accountants among others.

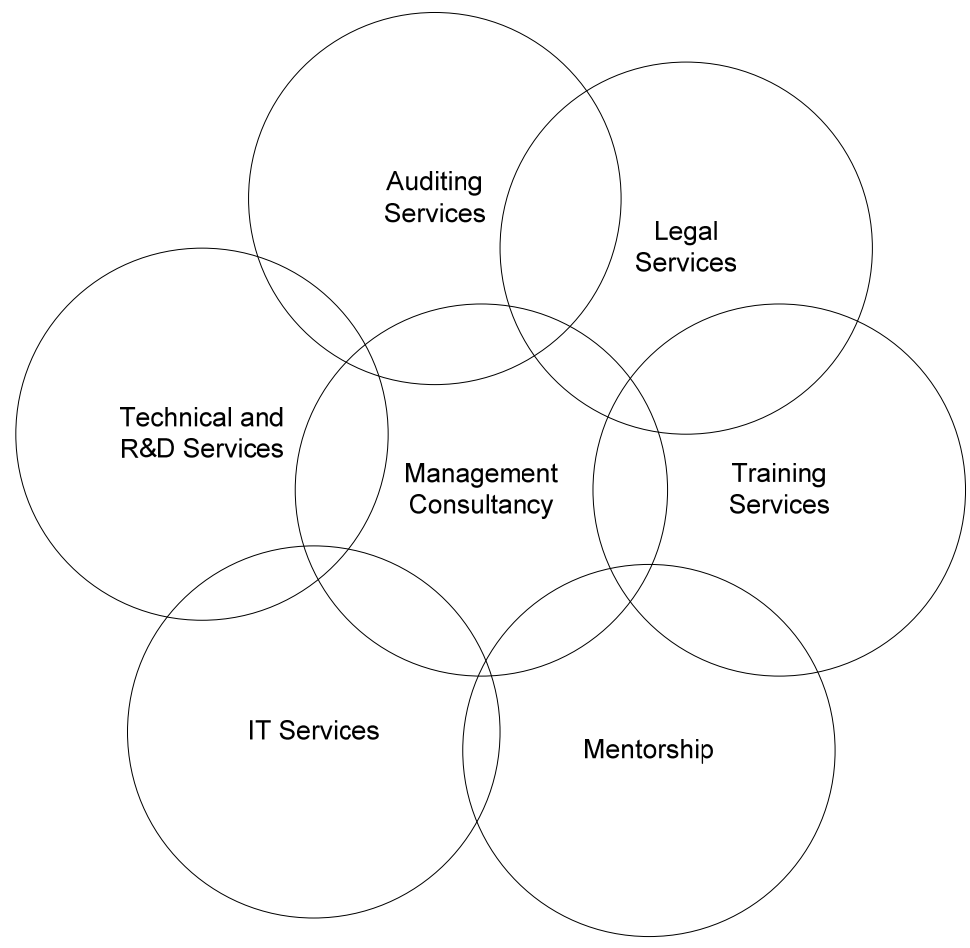

Figure 1 - A conceptual PBSO service offering with example overlaps (Based on Toivonen, 2004)

To avoid dealing with the transaction costs of developing such non-core competencies and to keep the PBSO small and lean, these firms tend to enter into collaborative arrangements (Das et al., 2000; Anand et al., 2000; Wysocki, 2004). Such arrangements allow collaborators to pool resources exploit complementarities and provide quick and flexible access to external resources (Das et al., 2000; Anand et al., 2000; Hoffmann et al., 2001; Belderbos et al., 2004). However the governance of such a PBSO collaborative enterprise can face unique challenges as demonstrated below:

- The challenge to derive a balance of collaborators' involvement in operational (core) processes at the organisational level, as well as, a strategy implementation (management processes), resulting in longterm sustainability of collaboration (Das et al., 2000);

- An unambiguous decision making process in which anticipated results are directly linked to the justification for the decision (expected 
benefits) and the means to support their delivery (resources) (European Monitoring Centre, 2005);

- A learning approach to strategy management where project results and performance are regularly appraised against the overall strategic goals of the collaborative enterprise (PBSO and its collaborators);

- Clear communication of the strategic priorities as well as the governance mechanism for the collaborative enterprise (Belderbos et al., 2004); and

- To maintain the project-based organisational strengths of coping with emerging situations and responding quickly to changing client needs (European Monitoring Centre, 2005).

The next section demonstrates the need for business process modelling to address the above mentioned strategic governance challenges for PBSO firms.

\section{Business Process Modelling}

Business process modelling is considered as an established way for organisations to identify bottlenecks in their processes (Vergidis et. al., 2008). In terms of PBSO, most of these bottlenecks are associated with the strategic and governance mechanisms employed within the organisations as stated in previous section. The BPR perspective consists of one-off revolutionary changes, while BPM strives to understand the key mechanisms of a business and hence, improve business efficiency (Van der Aalst et. al., 2003; Kohlbacher, 2010). Since the project processes in project-based organisations are quite mature, the bottlenecks can be across some management processes (Wysocki, 2004). Hence, from the PBSO perspective, Business Process Management (BPM) is more appropriate as compared to the Business Process Reengineering (BPR) trend.

Modelling techniques capture different aspects of a business process. The most common diagrammatic techniques for business process-modelling are flowcharts, Interim Data Exchange Format (IDEF), role activity diagrams, data flow diagrams and Petri-nets (Aguilar-Saven, 2004). Extensive literature (Aguilar-Saven, 2004; Bridgeland et al., 2009) is available on the different business process modelling techniques. The selection of one of these techniques to carry out business process modelling for an organisation depends on the objectives behind developing a process model for an organisation. Ideally, the process model needs to be developed with a tool or technique that is clear to understand, has standard syntax, easy to generate and accurate in representation. The initial phase of this selection depends on understanding of the research method adopted as well as the background of the organisation in question.

\section{Case Study Organisation - A background}

For the current research context, the case study organisation was an Small and Medium sized Enterprise (SME) services organisation. It is referred to as ProServe to maintain anonymity. ProServe is a management and advisory 
business. It is run by qualified people in the fields of Strategy, Organisational, and Alliancing. It is a small project-based organisation consisting of two Directors and hence, relies on collaborators for completing projects as well as for running some of the strategic activities within the organisation.

The selection of ProServe for the research project was ideal since it is a project-based organisation providing services (management advisory) for their clients hence being representative of similar PBSOs. In addition, it was part of a research project and hence had a special relationship with the university involved in the research project. To maintain the small and lean structure of the organisation, there is a dependence on external collaborators to take the role of Associates. However, since the organisation is a project-based organisation, the Associates do not know their organisational role when there are no projects. On the other hand, Directors expect the Associates to help with management activities such as finding new projects, developing case studies and other marketing materials, providing guidance for strategy development and implementation.

Previously, all these business activities were not explicitly stated in any document and hence, there was no apparent document to define the organisational roles for the Associates. In addition, a lack of a documented induction process made it difficult to integrate new collaborators or employees in this relationship or bring any required changes to the existing business processes. The interviewed Directors as well as Associates agreed that a document with the business processes and their process owners would help in clearly communicating the roles expected of each of individual.

All external collaborators took the project view of their work and hence, involuntarily distanced themselves from management processes such as finding new projects, development of new tools and technologies and development of marketing materials. This distance was forced by the lack of a communication of the collaborators' role at strategic level. The next section discusses the IDEF0 model requirements for ProServe.

\section{IDEF0 model for ProServe}

Business process modelling has its roots in systems engineering where complex interdisciplinary engineering projects need to be modelled (Climent et al., 2009). However, business processes in a PBSO can be hard to track since there are no physical manufacturing lines to follow the logical flow of the business process. Hence, there is a requirement for a process-mapping tool that can model a series of process instances that collaborate towards a common goal. The process model should help develop a flexible resource coordination model for performing projects (core processes) as well as carrying out strategic activities (management processes). The development of the process model began with the communication of the purpose of the exercise to Directors as well as Associates. It was followed by the identification of attributes that are important for the current context to be covered within the process model. The viewpoint of the process model was 
also decided upfront. In the current scenario, ease of collaboration was the viewpoint since SME PBSOs are highly dependent on such collaborations for getting a competitive advantage. .

The Directors of ProServe and the Associates were interviewed to find out their requirements from the process model to be developed. After getting views from both the parties, it was agreed that the process model needs to cover the following based on the viewpoint of process model development:

a. A formal model with standard syntax (language rules) for an enterprise (organisation and collaborators) wide consistency;

b. Supportive model documentation that would eventually help in determining the audit trails and different record keeping requirements for quality systems like ISO;

c. An adoptive model that is responsive to changes;

d. An easy to understand, user-friendly model. The model needs to have a degree of flexibility and thus, every possibility is not required to be represented within it; and

e. Lastly, it needs to be coherent and complete.

This research explored the development of a process model for the collaboration processes between ProServe and its Associates using the IDEF0 modelling system. The IDEFO method was selected for the process modelling since it has all the attributes that the Directors of ProServe preferred from the process model. In addition, IDEFO is industry as well as technology-independent, hence, easy to understand by Associates. In addition, it provides a means of drilling down from high levels to detailed views, so that the integrity of the system can be verified.

IDEFO was also preferred over other process modelling techniques, since it provided preferable properties, as evident from Table 1. From Table 1 it is clear that different modelling techniques provide different set of advantages. IDEFO is particularly strong in properties such as completeness and accuracy but a major weakness is that it is interpreted as a sequence of activities which is not always true in an organisational context. The IDEF0 modelling system is a structured design and analysis technique based on graphics syntaxes and semantics. This system provides the ability to produce a process model that is descriptive, as well as, comprehensive which was the requirement as previously noted in the business process modelling section of this paper.

Table 1: Required properties of the Business Process Model in the Current Context

\begin{tabular}{|r|l|l|l|l|}
\hline No & $\begin{array}{l}\text { Properties (Kock } \\
\text { et. al., 2009) }\end{array}$ & Description & $\begin{array}{l}\text { IDEF0 } \\
\text { strength }\end{array}$ & $\begin{array}{l}\text { Comparison with other } \\
\text { techniques (Based on } \\
\text { Aguilar-Saven, 2004) }\end{array}$ \\
\hline 1 & Ease of Generation & $\begin{array}{l}\text { How easy it is to } \\
\text { conceptualise, } \\
\text { create and use }\end{array}$ & Moderate & $\begin{array}{l}\text { Flow Chart - Strong; } \\
\text { Data Flow Diagrams - } \\
\text { Strong; } \\
\text { Petri-Nets - Very Weak }\end{array}$ \\
\hline
\end{tabular}




\begin{tabular}{|r|l|l|l|l|}
2 & $\begin{array}{l}\text { Ease of } \\
\text { Understanding }\end{array}$ & $\begin{array}{l}\text { Clear graphical } \\
\text { representation } \\
\text { and easy to } \\
\text { understand }\end{array}$ & Moderate & $\begin{array}{l}\text { Flow Chart - Strong; } \\
\text { Data Flow Diagrams - } \\
\text { Strong; } \\
\text { Petri-Nets - Strong }\end{array}$ \\
\hline 3 & Accuracy & $\begin{array}{l}\text { Accurate process } \\
\text { representation }\end{array}$ & Strong & $\begin{array}{l}\text { Flow Chart - Weak; } \\
\text { Data Flow Diagrams - } \\
\text { Moderate; } \\
\text { Petri-Nets - Strong }\end{array}$ \\
\hline 4 & Completeness & $\begin{array}{l}\text { Complete rather } \\
\text { than partial } \\
\text { representation }\end{array}$ & $\begin{array}{l}\text { Very } \\
\text { Strong }\end{array}$ & $\begin{array}{l}\text { Flow Chart - Weak; } \\
\text { Data Flow Diagrams - } \\
\text { Moderate; } \\
\text { Petri-Nets - Very Strong }\end{array}$ \\
\hline
\end{tabular}

The IDEF0 model presented incorporates all the business processes that the enterprise requires. The model presented here is composed of three levels opening with the context diagram, followed by parent diagram and child diagrams. The overall model aims to give an overview of all the important activities to effectively manage the strategic and operational management activities of the PBSO.

\section{Context Diagram}

Node CW is the context diagram that embodies the top level process. This top level process gives a general view of the management of a PBSO firm (refer to Figure 2). The context diagram provides the subject of the business model, the boundaries of the model as well as the external interfaces of the model. The process input consists of the prior experiences of the firm Directors, the client brief and the perceived market gap to produce outputs such as core service offerings, certified Associates, satisfied clients, etc. This process is carried out in the constraints such as external market conditions, regulations and IP rights. They develop into the controls of this arrangement. The mechanism of such a process consists of all the collaborative parties (in this case Directors, Associates, networks, etc) and the reviews and case studies of previous work.

This overall process model has the objective of proposing a strategic governance structure for the PBSO firm to operate in the project based environment and still be able to govern itself. For the current research, the overall process of managing a PBSO firm is put in context through this diagram. 

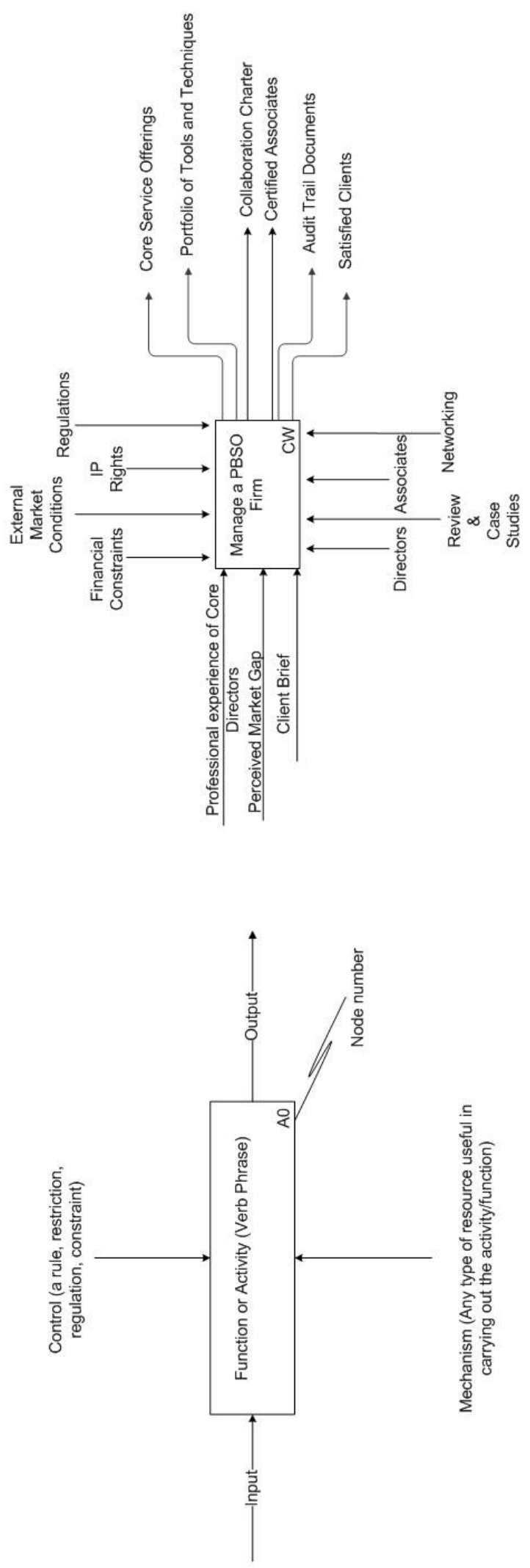

Figure 2: Context Diagram 


\section{Parent Diagram}

Node A0 (Figure 3) represents the parent diagram of ProServ's process of collaborative working. The identification of the main processes for the parent diagram consisted of identifying the major processes of managing the firm and then grouping them in three to six headings to form the main processes. These headings had to consider issues related to the nature of the services organisation like winning projects followed by execution as compared to production before sales in manufacturing organisations. It also had to consider issues related to the collaborative nature where special attention had to be given to the development of an associate team and training them before trying to find projects.

The process is hierarchical in nature as with most organisations and starts with the strategizing of the key sector portfolios. The professional experience of the Directors as well as the perceived market gap helps in strategizing key sector portfolios for ProServe, hence they are the inputs in A1. The strategising of the key sector portfolio is helpful in identifying the types of projects that ProServe would try to win in accordance to their work philosophy. At this stage, the mechanism to strategize key sector portfolios was the Directors with their knowledge and the market information available from trade organisations and other sources. The controls at that stage are the finances available with the founders (Directors) of ProServe along with the prevailing external market conditions and regulations/laws. A1 process helps ProServe in identifying its internal capabilities, core service offerings, corporate values as well as short, medium and long term financial and growth (SML Finance \& Growth) goals. Hence all of the above are the outputs of this activity.

The next process is to Acquire Portfolio of Tools and Techniques. The management and advisory business required different management tools and techniques to win professional services projects. The inputs to this activity were the perceived market gaps along with core service offerings and target sectors that activity A1 established (Figure 4). The market gaps gave an idea about the different tools and techniques required in the organisation while the target sectors along with core service offerings help in identifying the priorities for acquiring new tools. The controls for this activity consisted of the financial constraints of ProServe, the prevailing market conditions and the Intellectual Property rights for the tools and techniques. The activity was guided by the SML Finance \& Growth goals determined in A1. The owners of the licensed tools became strategic partners and hence mechanisms for this activity along with the books/manuals and presentations/workshops. The output of this activity is the portfolio of tools and techniques to provide the services to ProServe's clients as well as ProServe's training requirements for this portfolio. In addition the activity is also producing marketing materials and synergetic one stop solutions consisting of different tools and techniques for ProServe.

Establishing the core Associate team becomes the third process in the parent diagram. Limited availability of human resources within ProServe leads to 
skills shortage, resulting in a need to establish a core Associate team. The inputs to this activity consist of the SML Finance \& Growth and the perceived market gaps as evident from Figure 5 . The activity is regulated by the target industry sectors, the geographical coverage that ProServe can handle, the corporate values that ProServe wants to adhere by and the prevailing market conditions. The mechanism to carry out this activity consists mainly of the networking the Directors of ProServe conduct along with the interest shown by the prospective Associates. The output of this activity is a collaboration charter to guide the relationship between ProServe and Associates. In addition, training requirements of the Associates are identified after establishing the core Associate team and individual work targets for the Associates are also established.

Node A4 shows the training requirements of Associates along with the finance and growth goals, and the portfolio of tools and techniques as the inputs for the activity of managing Associate team training. The controls of this activity are the financial constraints of ProServe along with prevailing market conditions and the collaboration charter, while the mechanisms for the activity are the human resources (i.e. Associates and strategic partners) and presentations/workshops along with the library of books and manuals available to ProServe and its Associates. Sometimes additional inputs derived from case studies and reviews are also a mechanism to provide Associate team training. The outputs of this activity would be a team of trained and certified Associates. The knowledge of the portfolio of tools and techniques available with ProServe would also help Associates identify potential clients from their personal networks.

The penultimate process is to win new projects. The inputs of A5 activity are the portfolio of tools and techniques along with the trained Associate team and the client prospects identified by the Associates. In addition, previous project clients can provide with opportunities for repeat business. As pointed out in figure 7 , along with the controls of collaboration charter, financial constraints and prevailing market conditions, ProServe also depends on the Associates' time-in-kind for preparing bids and marketing for winning new projects. The mechanism to achieve the activity depends on the Associates and Directors attending networking events and using the different sources of media like internet and publications. The output of this activity would be formulated sales targets, weighted prospects list and rolling view of commitments from Associates along with the winning bids.

Eventually, the portfolio of tools and techniques along with the winning bid and the client brief are the inputs for executing the projects as shown in figure 8. The activity would be regulated by many factors such as the project finance plan, collaboration charter, financial conditions and regulations. The Directors as well as Associates are involved in executing this projects and the outcome of this activity are the satisfied clients, the project audit trail documents, case studies and reviews along with possible opportunities for repeat business. 


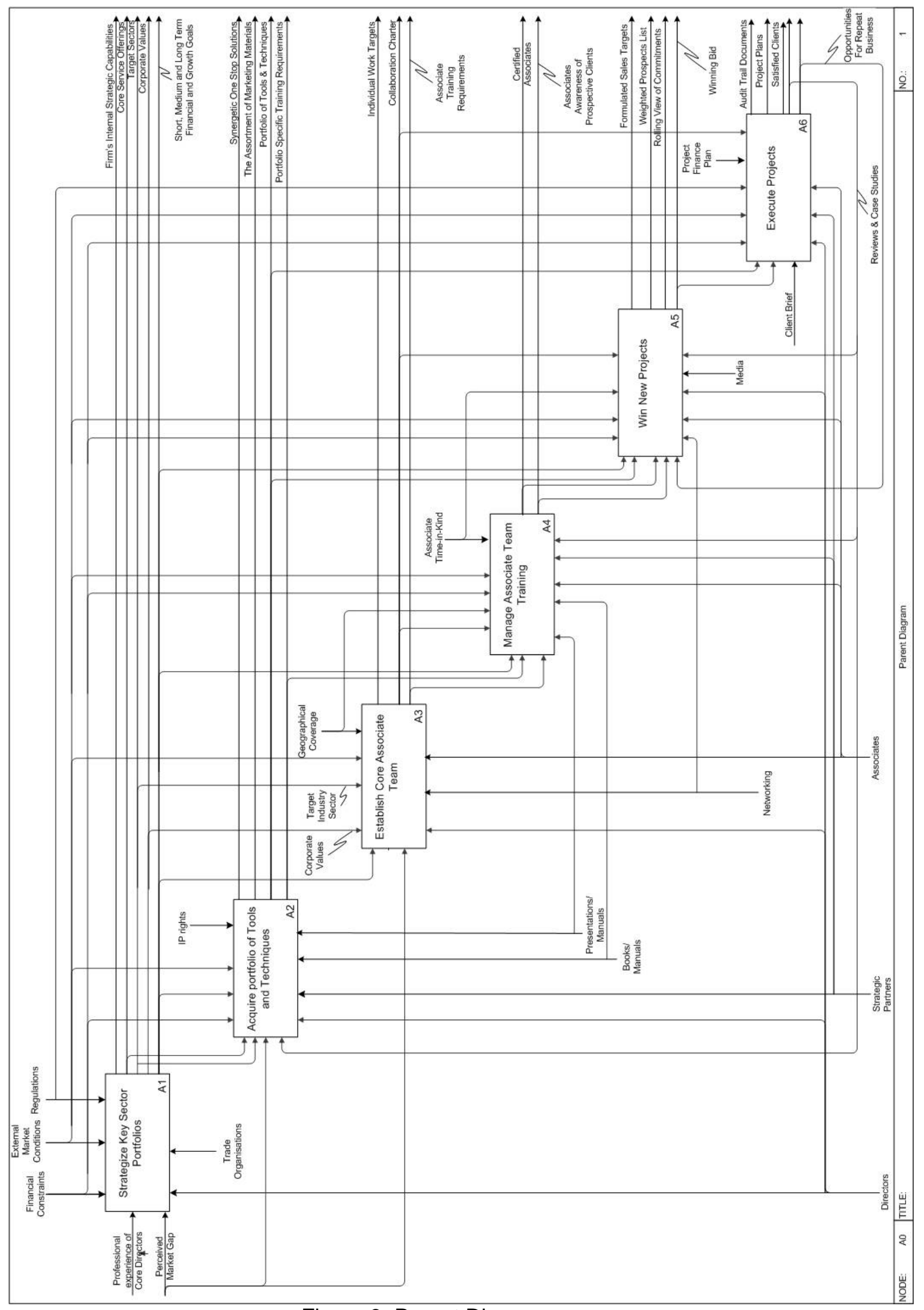

Figure 3: Parent Diagram 


\section{Child Diagrams}

Decomposition of the main activities was the next stage of IDEF0 development for ProServe collaboration. The decomposition of each of these main activities was carried out until the required level detail was obtained. The required level of detail for the current project is a stage where all the activities of ProServe and Associates are understood whilst making the roles of each collaborator and information flow is made clear. The table below (Table 2) provides the main sub-processes under each of the main processes (A1 to A6) resulting in 6 IDEF0 child diagrams.

Table 2: IDEF0 Sub-processes after decomposition of main activity

\begin{tabular}{|c|c|c|c|}
\hline $\begin{array}{l}\text { Main } \\
\text { Process } \\
\text { IDs }\end{array}$ & Main processes & $\begin{array}{l}\text { Sub- } \\
\text { process } \\
\text { IDs }\end{array}$ & Sub-processes \\
\hline \multirow{5}{*}{ A1 } & \multirow{5}{*}{$\begin{array}{l}\text { Develop a } \\
\text { Strategic Plan }\end{array}$} & A1.1 & $\begin{array}{l}\text { Identify internal strategic } \\
\text { capabilities }\end{array}$ \\
\hline & & A1.2 & $\begin{array}{l}\text { Identify core services and } \\
\text { value proposition }\end{array}$ \\
\hline & & A1.3 & $\begin{array}{l}\text { Develop financial and } \\
\text { growth goals }\end{array}$ \\
\hline & & A1.4 & Conduct market sensing \\
\hline & & A1.5 & $\begin{array}{l}\text { Decide the target sector } \\
\text { portfolios }\end{array}$ \\
\hline \multirow{5}{*}{ A2 } & \multirow{5}{*}{$\begin{array}{l}\text { Acquire portfolio } \\
\text { of tools and } \\
\text { techniques }\end{array}$} & A2.1 & $\begin{array}{l}\text { Collate/search tools and } \\
\text { techniques for core } \\
\text { services }\end{array}$ \\
\hline & & A2.2 & $\begin{array}{l}\text { License/Buy tools and } \\
\text { techniques }\end{array}$ \\
\hline & & A2.3 & $\begin{array}{l}\text { Develop appropriate } \\
\text { additional complementary } \\
\text { tools }\end{array}$ \\
\hline & & A2.4 & $\begin{array}{l}\text { Establish internal tools } \\
\text { synergies for one-stop } \\
\text { service offerings }\end{array}$ \\
\hline & & A2.5 & $\begin{array}{l}\text { create assorted } \\
\text { marketing for ProServe } \\
\text { tools and techniques }\end{array}$ \\
\hline \multirow{5}{*}{ A3 } & \multirow{5}{*}{$\begin{array}{l}\text { Establish core } \\
\text { Associate team }\end{array}$} & A3.1 & $\begin{array}{l}\text { Identify prospective } \\
\text { associates }\end{array}$ \\
\hline & & A3.2 & $\begin{array}{l}\text { Determine associate } \\
\text { expectations }\end{array}$ \\
\hline & & A3.3 & $\begin{array}{l}\text { Develop and sign a } \\
\text { collaboration charter }\end{array}$ \\
\hline & & A3.4 & $\begin{array}{l}\text { Conduct periodic } \\
\text { strategic workshops }\end{array}$ \\
\hline & & A3.5 & $\begin{array}{l}\text { Establish periodic review } \\
\text { process }\end{array}$ \\
\hline \multirow{2}{*}{ A4 } & \multirow{2}{*}{$\begin{array}{l}\text { Manage } \\
\text { Associate team } \\
\text { training }\end{array}$} & A4.1 & $\begin{array}{l}\text { Engage strategic partners } \\
\text { in associate training }\end{array}$ \\
\hline & & A4.2 & $\begin{array}{l}\text { Derive cost structure of } \\
\text { associate training }\end{array}$ \\
\hline
\end{tabular}




\begin{tabular}{|c|c|c|c|}
\hline & & & programs \\
\hline & & A4.3 & $\begin{array}{l}\text { Conduct associate } \\
\text { training programs }\end{array}$ \\
\hline & & A4.4 & $\begin{array}{l}\text { Receive training } \\
\text { feedback }\end{array}$ \\
\hline & & A 4.5 & $\begin{array}{l}\text { Create associate based } \\
\text { marketing strategy }\end{array}$ \\
\hline \multirow{4}{*}{ A5 } & \multirow{4}{*}{$\begin{array}{l}\text { Perform } \\
\text { marketing } \\
\text { activities }\end{array}$} & A5.1 & Create sales targets \\
\hline & & A5.2 & $\begin{array}{l}\text { Identify prospects/ Leads } \\
\text { generation }\end{array}$ \\
\hline & & A5.3 & $\begin{array}{l}\text { Populate the prospects } \\
\text { database }\end{array}$ \\
\hline & & A5.4 & Develop and submit bid \\
\hline \multirow{6}{*}{ A6 } & \multirow{6}{*}{ Execute projects } & A6.1 & Agree contract terms \\
\hline & & A6.2 & $\begin{array}{l}\text { Confirm project } \\
\text { associates and resources }\end{array}$ \\
\hline & & A6.3 & $\begin{array}{l}\text { Hold project kick-off } \\
\text { meeting }\end{array}$ \\
\hline & & A6.4 & Approve project plan \\
\hline & & A6.5 & Implement action \\
\hline & & A6.6 & $\begin{array}{l}\text { Provide post contract } \\
\text { services }\end{array}$ \\
\hline
\end{tabular}

These diagrams tackle all the activities of ProServe starting from the stage of developing a strategic plan. The strategic plan is a first step towards identifying internal core strategic capabilities to result in the confirmation of ProServe value as well as the core services it wants to provide. Once core services are identified, the directors felt the need to develop financial and growth goals, conduct market sensing exercises and eventually decide on the key target sector portfolios. These sub-processes would help develop the strategic plan as well as form the basis of finding the business for ProServe.

Acquiring a portfolio of tools and techniques was identified as the next stage of the ProServe's process. It consists of some activities that are not always sequential. The process would start with the collating as well as searching tools and techniques that can help ProServe provide the core services to its clients. This search can lead to one of the two ways of procuring tools and techniques, if there is something similar already available in the market and under the budget then ProServe will try to license or buy it. However, sometimes it is a cheaper option to develop tools complementing the required core services. Both these processes are almost parallel. The acquired tools can be from different industries and hence it is required for ProServe to establish internal synergies between these tools to provide a one-stop service offering portfolio. Lastly, assorted marketing materials needs to be generated based on the tools available.

Node A3 is the establishment of the associate team. The initial sub-process within this node is to find out prospective associates who might be interested in joining an organisation like ProServe for collaborative working. It is important according to the Directors as well as existing associates to find out the expectations of the prospective associates and communicate ProServe's 
expectation to form the basis of the collaboration charter. Conducting periodic workshops help in establishing trust and commitment towards the collaboration since it puts initiative on the associates to get involved in strategy planning and implementation along with the normal project activities.

Establishment of associate team is followed up with the process of managing the associate team training. It is important to engage the strategic partners into the associate training program for maximum benefits to all collaborators. This engagement will help prepare a cost structure to associate training based on their previous experience in the target area/tools and techniques. This is followed up with comprehensive training programs based on the requirements and interests of participants. The feedback from these programs helps to design and make changes to future programs. Lastly an associate based marketing strategy is created to obtain maximum benefits from this training.

The penultimate process is to perform marketing activities based on the strategy developed. The process contains the important sub-process of creating sales targets. The targets would help identify prospective projects and hence prospects and leads are generated. Once the prospects are uploaded on the prospects database and a decision is taken to bid for the project, the bid is developed and submitted.

The last process consists of executing the won projects. The process is initiated with the agreement on the contract terms. ProServe then needs to confirm the participation of project participants for the particular project as well as other resources. The project kick off meeting is the initiation of the actual project and first steps towards approving a project plan. It is followed by execution of the contracts and lastly information and feedback is collected and other post contract services are provided.

Below, two of these child diagrams are shown along with a comprehensive explanation of nodes, followed by a discussion on the validation of the process model.

Node A4 -

Node A4 (see Figure 4) represents the process of managing Associate team training within ProServe collaboration. The process begins with engaging the strategic partners in Associate training and to derive a cost structure that would be viable for all the concerned parties of ProServe, Associates and the strategic partners. The cost structure of these training programs are important to be worked out in advance, since ProServe might invest in some of these programs before getting a project and hence would take the risks involved. To share the risks, a cost structure needs to be prepared where Associates can part fund the training along with ProServe and strategic partners provide these trainings at a discounted rate. Hence, such trainings organised by ProServe provide a win-win combination of more number of people getting certified in such trainings resulting in greater rewards for strategic partners, ProServe gets a pool of certified Associates and Associates receives certification to develop their skills set. These periodic Associate training 
programs can range from simple half day presentations to comprehensive workshops.

An essential sub-process is to receive training feedback from Associates and certify Associates after completing appropriate training in different tools. Lastly, training feedback along with certified Associates and Associate awareness of prospective clients will help create an Associate based marketing strategy to market the certified Associates of ProServe collaborative as an important resource.

Within all the sub-processes of node A4, the available finances with ProServe will determine the spending on training programs and so is one of the important controls. In addition the prevailing market conditions would decide the priority of a particular type of Associate training program and hence is a control along with the collaboration charter in terms of getting sustained participation from Associates. The outcomes of node A4 are skilled and certified Associates, a list of prospects as suggested by Associates after their introduction to the new tools and a branding strategy for ProServe collaboration.

Node 4 is a good example of detailed processes in place to establish collaborators involvement in strategy implementation as evident from the after training feedback and the dependence of development of marketing strategy based on their experiences of being trained. In addition it gives a clear idea to a prospective client as well as associate on how new people would be trained to ensure succession planning within the collaboration. 


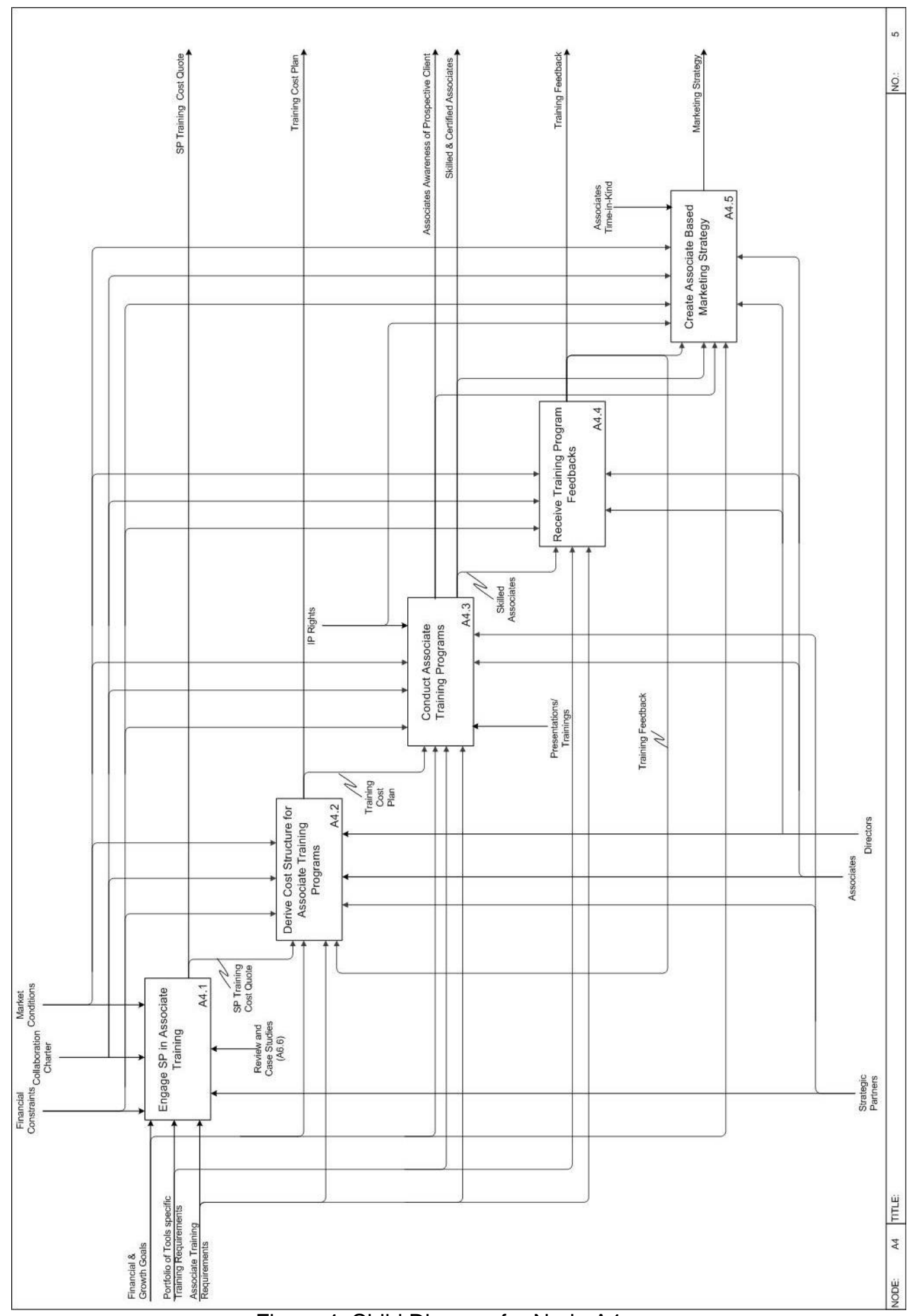

Figure 4: Child Diagram for Node A4 
Node A6 -

Node A6 (see Figure 5) stands for the process of executing projects. The process starts with the finalisation of the contract terms for the project with the clients. It proceeds then to confirm on the project Associates as well as other resources to be used for the project. Once the resources are committed, a project kick-off (initiation) meeting is held. The initiation meeting will clear the exact requirements of the clients and hence help generate a draft project plan which then needs to be approved. The approval stage could result in some alterations or revisions of the project plan. The approved project plan is then fed to implement the required actions. Lastly, successful actions and feedback of the actions help to provide the post contract services resulting in satisfied clients, project reviews, case studies as well as opportunities for repeat business.

A signed contract after the first sub-activity becomes an important control over the rest of the project sub-processes, along with other controls such as corporate values, project finance plan and collaboration charter. The signed contract is an exchange of promises between ProServe and the clients and hence it governs the sub-activities of Node A6. The project finance plan determines how the other sub-processes would be carried out while the collaboration charter as well as corporate values determines that every member involved in the project is gaining from the experience. In addition to the project team from ProServe collaboration, clients would aid the project. The different tools to gather data for analysis such as interviews and questionnaires are important mechanisms.

Node 6 is actually the node with activities that were mostly identified by the 'as is' model at the start when preliminary research was carried out. However, putting it in a detailed format as discussed above helps in generating a learning approach to the projects which leads to better strategic management of the collaborative relationship between ProServe and associates. Specifically the overall strategic goals of such an enterprise are revisited with the help of the case studies as well as project reviews at the end of the projects. The case study and project reviews are fed back to other processes to keep them informed about the strategic priorities in terms of getting new associates on board and their training to even targeting of the key sector portfolios. Lastly, node A6 ensures that the project-based organisational strengths of coping with emerging situations and responding quickly to changing client needs are maintained. 


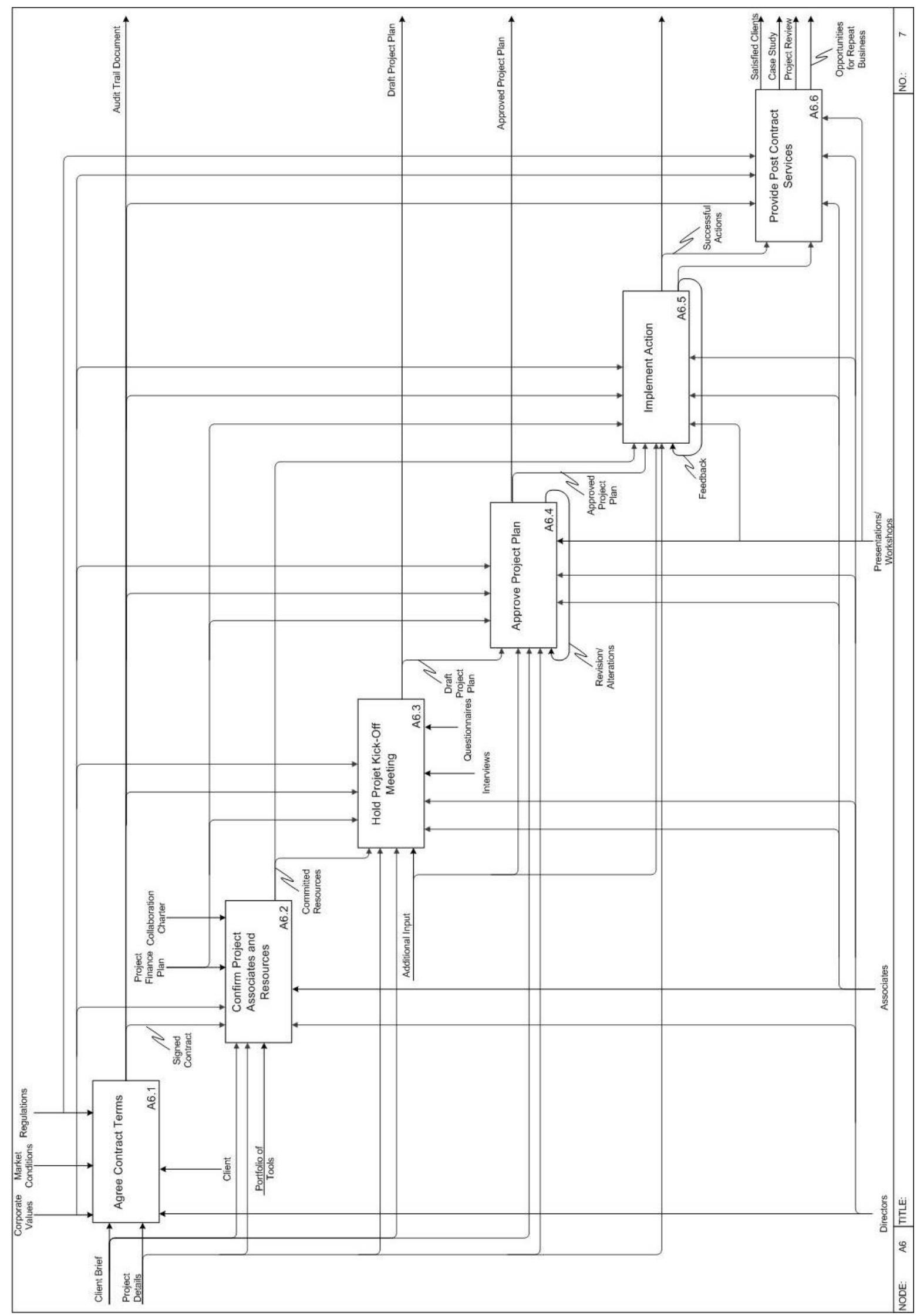

Figure 5: Child Diagram for Node A6

Validation 
The completed process model was validated against the issues identified at the start of the research. The interviewees felt that the process model helped to comprehend ProServe's expectations of the Associates and vice-versa. The exercise assisted in control and compliance within the collaboration directly resulting in clear decision-making processes. The interviewees were asked specific questions to validate the process model. One of the basic evaluation question was to ask the interviewees if they were involved in the preparation of the process model, to enhance their understanding of the model. In addition, they were asked if the IDEF0 model were simple to understand and if the process was hierarchical with interrelated activities, where the diagrams at the top of the model were less detailed then that of bottom. Lastly, they were asked of the prospective benefits of the new model.

The interviewees felt the new process model did ensure that the project based organisational work was maintained while taking care of the governance issues faced previously. This was achieved by isolating the project related work (core processes) in node $A 5$ and $A 6$ while node $A 1, A 2$ and $A 3$ primarily dealt with the strategy planning and implementation (management processes). Under all these nodes, the involvement of collaborators and hence process owners identified.

In addition, the interviewees pointed out the following additional benefits of this process model to give a better strategic work model for the organisation that is predominantly depending on external collaborators for certain important functions within the organisation. Specifically some of the additional general benefits that might be accomplished in any similar PBSO firm developing a comprehensive business process model are as follows:

- Communication of information requirements at each process stage - The process model helps to identify the different types of information either related to the controls over the process or the inputs for a process. The use of this process model communicates the delivery requirements at each stage for the different parties involved. Hence, it makes clear the role of the different collaborators in the PBSO.

- Generating service value - The processes related to the service creates more value when every collaborator involved knows why a certain process is required and the value of the output of that process. It helps to take out the non-value adding processes that might be noticed over a period of time due to continuous usage of the process model by the PBSO. Hence it is value enhancement of the processes carried out in an organisation.

- Enabling an auditable trail - A standard practice is useful in providing an auditable trail for the PBSO. An auditable trail is important for the organisation intending to get accreditation from organisations like ISO (International Standards Organisation).

- Better work planning for the collaborators - The collaborators of PBSO organisations are independent businesses or self-employed consultants. They would appreciate a standardised process as it helps them to better organise their daily diaries. 
- Information management - The proposed process model is helpful in generating accurate information that can be used for marketing purposes, for providing information to clients and for managing information internally.

\section{Concluding Discussions}

The introduction of the paper described the development of knowledge intensive service organisations as project-based organisations with collaborative arrangements. Such project-based service organisations give high importance to temporary work structures resulting in a struggle to integrate knowledge and provide the organisation's strategic intent. Hence, the context of this paper is project-based service organisations. The governance of such organisations faces unique challenges identified by literature dealing with service industry and project-based organisations. To find a solution for the above mentioned challenges, Business Process Modelling was chosen as a medium.

A detailed business process model was developed for a particular PBSO as a case study firm with the help of IDEFO modelling. The three tier decomposition of the IDEFO process model for the case study organisation aimed at giving an overview of all the important activities, effectively manages the core as well as management activities of the PBSO. The comprehensive process model of the case study organisation provided with the ability to enhance the collaborative relationships within the collaborative environment. These advantages can be generalised for other PBSO firms since they are deemed to face similar issues like:

- Establishing a balance between collaborators' involvement in operational management at the organisational level and strategy implementation, resulting in long-term sustainability of collaboration;

- An unambiguous decision making process with clear communication of strategic priorities;

- A learning approach to strategy management where project results and performance are regularly appraised against the overall strategic goals of the collaborative enterprise (PBSO and its collaborators); and

- Ensuring the project-based organisational strengths while helping the strategic management of the organisation with help of collaborators.

Apart from the benefit of providing an effective means to organise the core as well as management activities for similar PBSO, it generated other advantages, such as: communicating information requirements at each process stage, enabling an auditable document trail, generating service value, better collaboration and information management. Whilst there are general benefits for any PBSO organisation intending to develop a well-defined business process model, future research should get more evidence from similar organisations. Hence, organisations that involve collaborations from different organisations and people to provide service and the business process modelling developed with the help of IDEF0, provides a change from the traditional disjointed strategic management and governance of such firms. 


\section{References}

Aguilar-Saven, R.S. (2004). Business process modelling: Review and framework. International Journal of Production Economics. Vol. 90. pp 129149.

Anand, B. and Khanna, T. (2000). Do firms learn to create value? The case of alliances. Strategic Management Journal. Vol. 21. pp. 295-315.

Belderbos, R., Carree, M., Diederen, B., Lokshin, B., Veugelers, R. (2004). Heterogeneity in R\&D co-operation strategies. International Journal of Industrial Organization. Vol. 22. pp 1237-1263.

Bredin, K. (2008). People capability of project-based organisations - A conceptual framework. International Journal of Project Management, Vol. 26, pp. 566-576.

Bridgeland, D.M., Zahavi, R. (2009). Modelling Fundamentals. Business Modelling. Pages 19-40.

Climent, C., Mula, J. and Hernandez, J.E. (2009), 'Improving the business processes of a bank', Business Process Management Journal, Vol. 15, No. 2, pp. 201-224

Das, T., Teng, B. (2000). A resource-based theory of strategic alliances. Journal of Management. Vol. 26. pp 31-61.

European Foundation for the Improvement of Living and Working Conditions, 2005, 'Sector Futures - The Knowledge-Intensive Business Service Sector', Report by European Monitoring Centre on Change, pp. 2-29.

Hobday M. (2000). The project-based organisation: an ideal form for managing complex products and systems? Research Policy;29:871-93.

Hoffmann, W.H., Schaper-Rinkel, W. (2001). Acquire or ally - A strategic framework for deciding between acquisition and collaboration. Management International Review. Volume 4. pp. 131-159.

Lindkvist L. (2004). Governing project-based firms: promoting market-like processes within hierarchies. Journal of Management Governance 2004;8:325.

Kock, N., Verville, J., Danesh-Pajou, A., DeLuca, D. (2009). Communication flow orientation in business process modelling and its effect on redesign success: Results from a field study. Decision Support Systems. Vol. 46. pp 562-575.

Kohlbacher, M. (2010), 'The effects of process orientation: a literature review', Business Process Management Journal, Vol.16, No. 1, pp. 135-152 
Melao, N., Pidd, M., 2000. A conceptual framework for understanding business process modelling. Information Systems. Vol. 10, pp 105-129.

Paper, D. (1998). BPR: Creating the conditions for success. Long Range Planning. Vol. 31. No. 3. pp 426-435.

Ritter, T., Gemunden, H.G. (2004). The impact of a company's business strategy on its technological competence, network competence and innovation success, Journal of Business Research. Vol. 57. pp 548-556

Soderlund J. (2000) Temporary organizing: consequences and control forms. In: Lundin RA, Hartman F, editors. Projects as business constituents and guiding motives. Boston: Kluwer Academic Publishers.

Stake, R. E. (1995). The art of case study research. Thousand Oaks, CA: Sage.

Sydow J, Lindkvist L, DeFillippi R. (2004). Project-based organizations, embeddedness and repositories of knowledge: editorial. Organisational Studies ;25(9):1475-89.

Thiry, M., Deguire, M., 2007, Recent Developments in Project-based Organisations, International Journal of Project Management, Vol. 25, pp. 649 -658 .

Toivonen, M. (2004). 'Expertise as business: Long-term development and future prospects of knowledge-intensive business services (KIBS)', Helsinki, Helsinki University of Technology, Doctoral dissertation series 2004/2, available at: http://lib.tkk.fi/Diss/2004/isbn9512273152/ last visited on 15/06/2009.

Vergidis, K., Turner, C.J., Tiwari. A. (2008). Business process perspectives: Theoretical developments vs. real-world practice. International Journal of Production Economics. Vol. 114. pp 91-104.

Whitley R. (2006). Project-based firms: new organizational form or variations on a theme. Industrial Corporate Change. Vol.15. pp 77-99.

Wysocki, R.K. (2004). Project management process improvement. Artech House, London

Van der Aalst, W.M.P., Van Dongen, B.F., Herbst, J., Maruster, L., Schimm, G., Weijters, A.J.M.M. (2003). Workflow mining: A survey of issues and approaches. Data and Knowledge Engineering. Vol. 47. Issue 2. pp 237-267.

Yin, R.K. (1994). Case study research: Design and methods, second ed. Sage Publications, Thousand Oaks, CA. 